Lewin, R. A. (1952). J. gen. Microbiol. 6, 249-250.

\title{
The Primary Zygote Membrane in Chlamydomonas moewusii
}

\author{
By R. A. LEWIN \\ Osborn Botanical Laboratory, Yale University, New Haven, Conn., U.S.A.
}

SUMMARY: In Chlamydomonas moewusii the primary zygote membrane (PZM) is formed at the initiation of gamete fusion. The PZM of C. moerousii does not appear to be composed of cellulose or pectic material; it stains readily with Schiff's reagent which suggests the presence of free aldehydic groups. Several recently isolated strains of Chlamydomonas show this reaction which is presumed to be common to the genus.

The fusion of gametes in Chlamydomonas paupera is followed by the formation of a 'primary zygote membrane' (PZM) (Pascher, 1931-2). Within this membrane the thick-walled zygospore is formed, and the PZM is ultimately shed. A similar series of events has been described for C. braunii (Goroschankin, 1890), Chlorogonium oogamum (Pascher, 1931), Gonium pectorale (Schreiber, 1925) and Sphaeroplea spp. (Fritsch, 1929): it is probably of widespread occurrence, at least among the Volvocales.

In Chlamydomonas moewusii Gerloff, deposition of the PZM commences at the initiation of gamete fusion, before the nuclei have come together. The gametes of this species resemble the vegetative cells, and are each enclosed in a thin cell-wall; but these walls are shed during cell fusion, remaining attached to the PZM as delicate hyaline vesicles. In conditions of constant artificial illumination the formation of the true zygospore wall within the PZM begins within $24 \mathrm{hr}$., and after $48 \mathrm{hr}$. has achieved its final form, being considerably thickened and sculptured with a coarse reticulum. Since these changes are accompanied by considerable enlargement of the zygospore, the PZM is usually ruptured in the process, and may be shed and completely freed from the spore (Pl. 1, figs. 3, 4).

The walls of the vegetative cell of the gamete and of the mature zygospore appear birefringent under crossed Nicols, and are presumably cellulosic in nature. The PZM, on the other hand, does not exhibit this feature, nor does it stain with ruthenium red, indicating that it is composed of neither cellulose nor pectic material. Goroschankin (1890) reported that the PZM in C. braunii stained blue with Schultze's reagent, chloriodide of zinc, differing in this respect from the walls of vegetative cells and zygospores. This was not found to be the case in $C$. moerousii. The mature zygospore wall of $C$. moerousii is extremely impermeable, but the PZM permits the penetration of dyes (e.g. gentian violet): these observations are in agreement with those of Schreiber (1925) on Gonium pectorale. Unlike the walls of vegetative cells and zygospores, the PZM of $C$. moewusii stains readily within a few minutes when treated, without prior hydrolysis, with Schiff's reagent (fuchsin decolorized with $\mathrm{SO}_{2}$ ) 
(Pl. 1, figs. 1, 2). This suggests the presence of free aldehydic groups within the membrane. There is some confirmation of this in the fact that the colour is immediately bleached by alkali and reversibly restored by acid, which is said to be indicative of aldehydic substances (Oster \& Mulinos, 1944).

Sexual strains of three homothallic and three heterothallic species of Chlamydomonas have recently been isolated, from a ditch in Long Island, N.Y., from a greenhouse in New Haven, Conn., and from soil samples collected in Arizona (Lewin, 1951). In every case these species resembled C. moewusii in that only the PZM became stained on treatment with Schiff's reagent; so it may be presumed that this reaction is common to members of the genus.

Prát (1947), in a study of the reaction of algal cell walls to Schiff's reagent, tested vegetative cells of fifteen species of Chlamydomonas, as well as members of other genera of the Volvocales, and in no case observed recoloration of the dye. He found, however, that whereas the normal vegetative cell walls of Spirogyra spp. (Conjugales) do not stain with this reagent, the walls of copulating cells, especially in the region of the copulation tube, stain deeply within a few seconds. This difference between walls of vegetative cells and those of cells undergoing sexual fusion is thus closely parallel with that described above for Chlamydomonas.

No suggestion is put forward as to the significance of this reaction.

\section{REFERENCES}

Fritsch, F. E. (1929). The genus Sphaeroplea. Ann. Bot., Lond. 43, 1.

Goroschankin, J. (1890). Beiträge zur Kenntnis der Morphologie und Systematik der Chlamydomonaden. Bull. Soc. Imp. Nat. Moscou., N.S. 4, 498.

Lewin, R. A. (1951). Isolation of sexual strains of Chlamydomonas. J. gen. Microbiol. $5,926$.

Oster, K. A. \& Mulrnos, M. G. (1944). Tissue aldehydes and their reactions with amines. J. Pharmacol. 80, 132.

Pascher, A. (1931). Über einen neuen einzelligen und einkernigen Organismus mit Eibefruchtung. Beih. bot. Z Zl. 48, 466.

Pascher, A. (1931-2). Úber Gruppenbildung und 'Geschlechtswechsel' bei den Gameten einer Chlamydomonadine (Chlamydomonas paupera). Jb. wiss. Bot. 75, 551.

Prát, S. (1947). The reaction of algal cells with Schiff's reagent. Acta Fac. Rerum Nat. Univ. Carolinae, 177, 1.

Schreiber, E. (1925). Zur Kenntnis der Physiologie und Sexualität höherer Volvocales. Z. Bot. 17, 337 .

\section{EXPLANATION OF PLATE}

Fig. 1. Young zygote among vegetative cells. (Schiff's base: $\times 1000$.)

Fig. 2. Two zygotes - one germinating, the other collapsed. (Schiff's base: $\times 1000$.)

Fig. 3. Mature zygospores with PZM. (Unstained: $\times 500$.)

Fig. 4. Empty zygospore wall with PZM. (Unstained: $\times 1000$.) 
Journal of General Microbiology, Vol. 6, Nos. 3 and 4

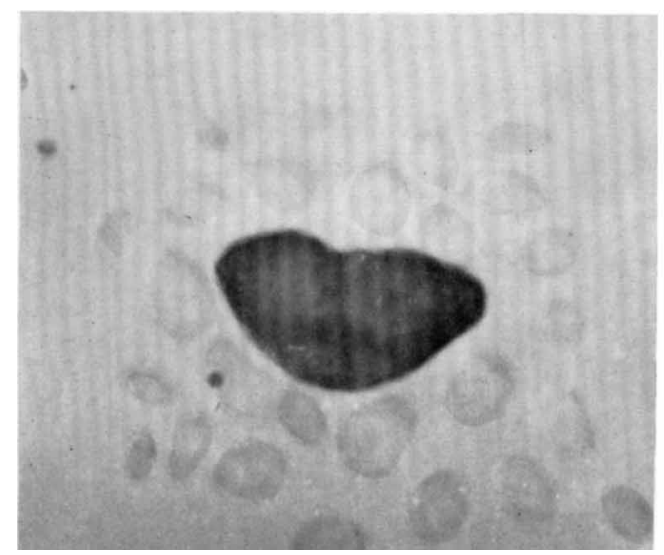

Fig. 1

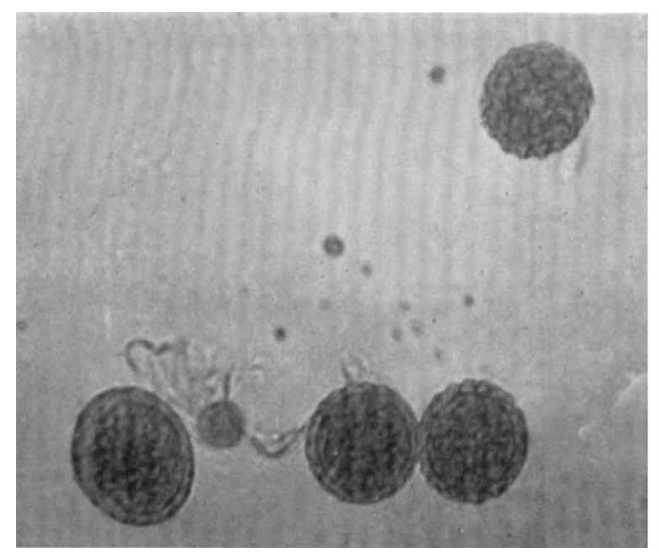

Fig. 3

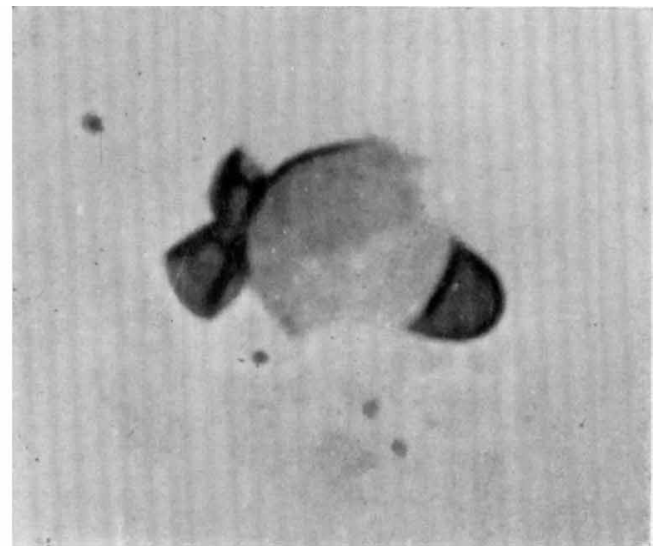

Fig. 2

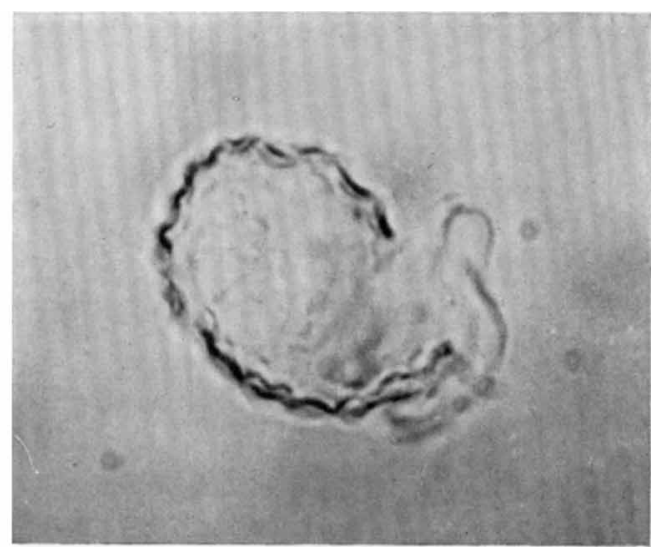

Fig. 4

R. A. Lewin-Primary zygote membrane in Chlamydomonas moewdsil. Plate 1 